\title{
Unusual Factors Contributing to Economic Turmoil
}

\author{
Remarks by DARRYL R. FRANCIS, President, Federal Reserve Bank of St. Louis, \\ Before The Wesleyan Associates, Illinois Wesleyan University, \\ Bloomington, Illinois, December 6, 1974
}

\begin{abstract}
$\mathrm{T}$
HE YEAR we are about to end has been very unusual in that it was characterized by one of the most rapid increases in the price level, and by one of the sharpest drops in reported real output in the postWorld War II period. In order to understand the view we hold at the Federal Reserve Bank of St. Louis regarding the outlook for 1975 , it is necessary to take time to develop, in some detail, the interpretation we apply to the events in 1974 .

First, let's review some definitions of economic concepts. We all talk about inflation; we hear a lot about inflation; but I think that there are some inaccurate ideas prevailing in the press and in the minds of the general public as to what the phenomenon called inflation really is. Inflation is simply a process involving erosion of the purenasing power of a nation's money supply - that is, simply a deterioration in the exchange rate between money and goods and services.

I use the word "process" because intlation is an ongoing phenomenon; it is continuous, although not necessarily at a steady rate. This is distinct from a price increase, or an increase in the price level that is not continuous, or ongoing. That distinction becomes very crucial to understanding the forces infuencing our economy and general welfare in 1974 .
\end{abstract}

The general phenomenon of a continuous inflation is due basically to monetary causes. Normally, we attribute inflation to a growth in the nation's money supply which produces a growth of total spending at a rate faster than the growth in real ontput - in other words, too much money chasing too few goods. Since inflation is a decline in the purchasing power of money, I think that there can be little quarrel with the general idea that inflation is a monetary phenomenon.

However, while a persistent inflation occurs only as the growth in money supply and resultant total demand for goods and services exceeds the total supply of goods and services, a temporary or transitory inflation can result from forces which produce a decline in the supply, or ability to produce goods, while demand continues to grow. In other words, a temporary bulge in the rate of inflation, while the economy is adjusting to a new higher equilibrium price level, is not neces. sarily associated with a marked acceleration in the rate of growth of the money supply. On the contrary, it can be associated with a steady, continuing growth of the money supply and aggregate demand for goods and services, while at the same time there is a sudden drop in the economy's real economic capacity.

It is our view that both a persistent monetary inflation and a temporary bulge in the rate of inflation occurred in 1974 in the United States and in many other countries of the world. Our analysis holds that the trend growth in the nation's money supply this year and over the past four years is consistent with an ongoing, sustained rate of increase in the general price level of about 5 to 6 percent per year. This year, how ever, we have seen both the GNP implicit price deflator and the consumer price index increase in excess 
of 12 percent. This is an increase that we do not believe can be explained by the growth of the money supply, either this year or over the past few years.

We attribute about half of the increase in the general price level this year to the trend growth of the money stock, and about half to forces which constrained the real economic capacity of the U. S. economy. We consider these forces to have only a one-time, transitional effect, although the process is distributed over a period of time that has so-far lasted about four quarters.

Given this view, we would argue that the rate of increase of the general price level will decelerate to the range of 5 to 6 percent per year, even if the rate of growth of the nation's money supply were to continue at about the same average pace observed over the past several years. To put it another way, we think about one-half of the inflation observed this year was of the persistent excessive aggregate demand variety, and about one-half was of the temporary, or transitory, variety. The latter occurred as the economy adjusted to a lower real economic capacity, and therefore, a higher equilibritum level of average prices.

Allow me to take a few moments to review the developments of the past few years. During 1967 and 1968 there is no doubt that stabilization policies in the United States were highly expansionary. This con" tributed both to an acceleration in the rate of inflation and to a high rate of real output growth accompanied by a low rate of unemployment. In 1969 monetary actions turned decisively restrictive as monetary policymakers sought to curb the building inflationary pressures. The actions taken in 1969 , as indicated by a marked reduction in the rate of growth of the nation's money stock, produced a slowdown in aggregate demand in 1970 and resulted in conditions that were characteristic of the previous business cycle recessions in the post-World War II period. Quite appropriately (and some time after the fact) the National Bureau of Economic Research declared that a recession had occurred, lasting approximately from November 1969 to November 1970.

During 1970 the rate of growth of the nation's money stock reaccelerated as policymakers sought to cushion the weakening economy. At the same time, the Federal Government's budget produced a deficit, indicating (according to the usual analysis) that fiscal policy was also stimulative.

In 1971 the growth of the money stock accelerated further and, then again in 1972 another step-up oc- carred. It was not surprising that growth in the demand for goods and services rose markedly through this period. I would argue that forces were at work contributing to the building of a familiar inflationary process, wherein too much money is chasing too few goods as the economy approaches its real economic capacity. Thus, we saw an erosion of the purchasing power of the nation's currency.

The inflation was not directly observable in the second half of 1971 and throughout 1972 since the Government chose to impose a rather rigid system of wage and price controls. These controls, if nothing else, had the effect of holding down the reported increases in prices, and therefore, the rise in the price indices. However, the system of controls began to break down, as was inevitable, and early in 1973 the Administration switched to a much less rigid program of controls, thereby allowing a catchip to begin. Throughout 1973 the rate of price increase, as measured both by the consumer price index and the GNP deflator, accelerated sharply as the process of de-control allowed the markets to begin to take us back to conditions consistent with underlying economic forces.

The growth of the nation's money stock in 1973 was somewhat slower than the rate experienced in 1972, but was still at a very high rate by historical standards. According to some empirical research at the Federal Reserve Bank of St. Louis, even though the rate of price increase in 1973 was much more rapid than implied by the growth in the money stock that year and in the years immediately prior, the price level at the end of 1973 was below the one indicated by the growth of the money stock over the prior few years. In other words, this research indicates that in the second half of 1971 and throughout 1972 the price level was being held below what the prevailing monetary growth would have implied. Therefore, in 1973 the high rate of price increase was simply the expected consequence of the removal of controls and return to the rate of exchange between money and goods that would bring us back to equilibrium conditions. In other words, after the re-adjustment or "catch-up" process was completed, we would expect a level of prices, as indicated by monetary growth, to prevail.

It is our judgment that the distortions on prices caused by controls and de-controls had pretty well worked themselves out by the end of 1973. Moreover, we would argue that the rate of inflation in 1974 would have been less than in 1973 (and only about half what has actually been observed in 1974) if there had not been a succession of what have become 
known as "special factors" which were providing further shocks to the economy.

One of the factors affecting relative prices (and therefore production) in the past few years is related to the depreciation of the dollar that occurred since 1971. The fact that the depreciation occurred indicates that the U.S. price level was out of line with its major trading partners. What had happened was that in the late 1960s and early 1970s, as the United States was pursuing inflationary policies associated with large Government deficits and a high rate of military spending, the international agreement on exchange rates (known as Bretton Woods) served to hold down prices of foreign goods to American consumers and producers, while raising prices of our goods to foreigners.

This means that for a number of years we were experiencing less inflation to the extent that foreign goods, in relative terms, became successively cheaper. Also, our goods were not being demanded in the same quantities that would have otherwise occurred. But once the dollar was permitted to depreciate, there were sharp shifts in underlying conditions. Demand for some goods declined and demand for other goods increased, bringing about marked shifts in relative prices to U. S. consumers. The prices of foreign goods rose sharply, while the prices of our goods to foreigners decreased sharply in terms of their currencies. Since foreign goods were now more expensive to us, American consmemers and producers shifted their demands away trom foreign goods and towards the relatively cheaper American produced goods. Similarly, the now cheaper American goods caused foreigners to step-up their purchase orders of our products. The adjustment to these sudden changes in relative prices naturatly would be distributed over an extended period of time.

In addition to the shifts in demand and the associated changes in relative prices caused by the dollar depreciation, the American social and political process restlted in decisions to shift the utilization of some of our nation's resources away from the production of conventional goods and services and towards a healthier living environment and a safer working environment. These laws took many forms, but basically they have been geared towards less pollution of the air by our factories and automobiles; less pollution of our nation's rivers and a safer working environment, as well as safer automobiles to transport American citizens. These decisions to re-allocate a share of our resources towards these objectives naturally implied significant shifts in demand, for both labor and other resources, away from the production of "widgets" and towards the production of clean air, clean water, and greater safety.

In the language of economists, these decisions essentially amounted to a change in our society's consumption basket, wherein we decided to forego the production of some goods, both now and in the future, in favor of the rather intangible benefits of less pollution and more safety. Given limited resources, such a re-allocation of resource utilization necessitates a reduction in our ability to produce the usual types of goods and services. In other words, we made a social and political decision which resulted in an absolute decrease in our production capacity for goods and services.

Furthemore, there were other factors at work constraining the domestic supply of goods. Crops around the world were not good in 1972. Foreign exchange rates were changing in the direction that made American goods look cheaper, and at the same time foreign countries were producing less grain, less anchovies, and so on; so naturally the demand for American agricultural products increased markedly. And we met that demand through very large increases in the volume of goods exported. Consequently, it should not be surprising that there were less goods and services available for American consumers.

Then late in 1973 the oil producing and exporting countries outside the United States (called OPEC) took collusive action to bring about a sharp increase in the world price of petroleum products. Let me digress a moment and characterize what had been going on. The OPEC group had been selling their oil output to the Westem world countries at prices that now look quite low indeed. With the revenue received from oil, they purchased goods and services from the Western world. In other words, viewed in barter terms, they were exchanging current output of oil for current goods and services produced by others. By agreeing to raise prices, the OPEC group, in effect, decided that they wanted to receive not only claims to current output in the Western world in exchange for vil, but also claims to future output.

The way this takes place is that we wind up selling securities to them, either equities or bonds, which represent clains to our future production of goods and services. In a very crade sense, we are now giving up some of our future production in exchange for some of their present oil. Even at the higher prices, apparently we are willing to do so rather than accept the altemative of reducing our current rate of oil consumption. Nevertheless, the effects are the same: 
U. S. consumers have had a wealth loss. We have been made poorer by the actions of the OPEC cartel. The standard of living of American consumers has been reduced, and probably will grow at a slower rate, because of the higher price of oil. The effects of the higher price of oil and substitute sources of energy have created massive shifts in demands, and therefore relative prices, which has been a dominant factor in the developments experienced in 1974.

The higher cost of energy, together with the environmental and safety laws, acts as a tax imposed upon the economic productive capacity of the United States. This means that the present value of the existing capital stock was reduced in much the same way as the value of the capital stock would decrease if the Government were to increase sharply the corporate $\operatorname{tax}$ rate. The decrease in the present value of the capital stock means that equity prices on the stock market decrease, reflecting the fact that the expected real earning power of corporations has been reduced by these varied actions.

The decrease in the real economic capacity of the country is, by and large, a one-time occurrence. However, the shifts in demand and changes in relative prices to adjust to a new equilibrium take some time to be fully completed. So far, this year has been one of four calendar quarters of shortages, sharp increases in the prices of many commodities, and a marked decrease in the reported volume of real output; but at the same time a continued high level of total employment.

This latter development, a rather high level of total civilian employment, is a development that I do not believe has receiver sufficient attention this year. The unemployment rate has been widely publicized, but the total number of persons employed has not been. The very sharp increase in the price level, even though about half the rate of inflation was transitory, did have the effect of reducing the standard of living of American consumers. That's part of the adjustment process. But because of the inflation, many persons who were not otherwise counted as part of our labor force - such as women, and young people - were induced to declare their intentions to seek jobs. More women found it desirable to work to supplement family income, and students chose to postpone entering or returning to college. This increase in the overall participation rate in the labor force was very large by historical standards. The increase in the participation rate was much faster than the ability of the economy to absorb these new job-seekers.
But why dwell on the fact that about one-half of the number of new persons seeking jobs did not find them, while neglecting the fact that one-half of these new entrants into the labor market did find jobs. Since one of the inputs to production - energy - has increased sharply in cost, our economic analysis tells us that the demand for other inputs to production, such as labor, would increase since the cost of these other inputs have become relatively cheaper. Since the present value of the existing capital stock in the U. S. economy has declined, there is naturally an increase in the demand for additions to capital stock; and therefore we have had an investment, or capital goods, boom throughout this year. That's what we would expect under the circunstances; and the fact that it takes quite a bit of time to put new plant and equipment in place indicates to me that, in the short run, firms will seek more labor as a temporary substitute for capital as they try to maintain production while waiting to restore real economic capacity.

The so-called "real output" numbers derived from the national income accounts give us an idea about changes in the volume of goods and services produced over time. But if we are devoting a much larger proportion of our resources to the production of such things as a cleaner environment and safer working and living conditions, then I believe it is appropriate to be skeptical of interpretations of the falling real output as being solely indicative of a sluggish economy.

Look at what goes into producing 1975 automobiles; in addition to the pollution control and safety devices on the automobile itself, there are environmental and safety restrictions imposed on the manufacturing process. And I think that in terms of inputs, the auto industry contimed to command a very large share of our resources until very recently, even though the volume of outputs, measured simply as the number of cars, declined.

With this analysis as background, let me turn to a few remarks about appropriate stabilization policy actions. On the one hand there is a temptation to want to do something about the 12 percent inflation, and on the other hand there is the desire to do something about the falling real output and rising unemployment rate. According to my interpretation of the events of the last few years, I believe that, without further special actions on the part of either monetary or fiscal athorities, and continuation of monetary growth at the 1973-74 rates, the rate of inflation will decelerate markedly next year to the range of 5 or 6 percent. At the same time, the growth in real output 
should resume and I doubt that the rate of unemployment will rise as high as some analysts have feared.

We have had a wealth loss; our standard of living has declined, and our absolute real economic capacity is now lower than it was a year ago. We should not seek policies designed to close the gap between what we are now producing and what could be interpreted as being real potential before the energy crisis, the environmental laws, the safety laws, the agricultural short-falls, and so on. That is simply unobtainable. Instead, we are forced to be satisfied to see a resumption of the growth rate of real output consistent with long-term growth trends in population, technology, and so forth - in other words, around three to four percent. But let me quickly add that this would also occur without any overt actions by government policymakers. As long as we do not suffer any further adverse shocks to the economy, I believe that the wherent stabilizing properties and the resiliency of the market system will return us to our potential growth path.

If Congress wishes to take some sort of action to increase the total output of consumers' goods, then it will have to think in terms of relaxing the environmental and safety standards imposed on industry generally and on specific consumer products, such as automobiles. Short of that, more spending programs to simply augment aggregate demand runs the risk of creating conditions leading to further acceleration in our underlying, permanent rate of inflation.

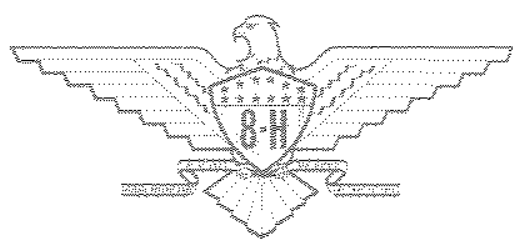

